\title{
Mycetoma: epidemiology, treatment challenges, and progress
}

This article was published in the following Dove Press journal:

Research and Reports in Tropical Medicine

5 June 2015

Number of times this article has been viewed

\author{
Hala Taha Mohamed' \\ Ahmed Fahal \\ Wendy WJ van de Sande ${ }^{2}$ \\ 'Mycetoma Research Center, \\ University of Khartoum, Khartoum, \\ Sudan; ${ }^{2}$ Department of Medical \\ Microbiology and Infectious Diseases, \\ Erasmus MC, Rotterdam, \\ the Netherlands
}

\begin{abstract}
Mycetoma is a chronic infectious disease of the subcutaneous tissue with a high morbidity. This disease is most commonly seen in countries between $30^{\circ} \mathrm{N}$ and $15^{\circ} \mathrm{S}$ of the equator, but cases have also been seen in Europe and the USA. Due to the lack of proper prevalence data, currently the true burden of this disease is not known. Mycetoma can be caused by a large variety of microorganisms, both bacteria and fungi. Treatment of the disease depends on the etiology of the causative agent. Actinomycetoma is usually treated with antibiotics only and has a decent cure rate; eumycetoma is treated with a combination of antibiotics and surgery. Unfortunately, for eumycetoma, recurrent infections are common and amputations are still needed in a large proportion of the patients.
\end{abstract}

Keywords: eumycetoma, actinomycetoma, epidemiology, etiology, therapy

\section{Introduction}

Mycetoma is a specific chronic, granulomatous, inflammatory disease. It usually involves the subcutaneous tissue, most probably after traumatic inoculation of the causative organism. It has a prolonged, progressive, and indolent course, and, if untreated, it ultimately leads to destruction of the deeper tissues and bone, resulting in deformity and disability that may necessitate amputation of the affected parts with all the social and economic implications of this. ${ }^{1}$ The disease is characterized by tumefaction, draining sinuses, and the presence of grains (Figure 1).

\section{Causative agents}

Mycetoma may be caused by true fungi or by higher bacteria of the class actinomycetes and hence it is classified as eumycetoma or actinomycetoma, respectively. ${ }^{1-3} \mathrm{~A}$ large variety of microorganisms from various genera and species are capable of causing mycetoma $^{1}$ and several of these organisms seem to have their natural habitat in soil or plant materials including thorns (Table 1) ${ }^{4,5}$ Characteristic for mycetoma is that, upon entering the human body, the causative agents organize themselves in granules called grains. These grains are probably formed as a defense mechanism against the human immune system. ${ }^{1-3,5}$ Since so many different microorganisms are able to cause mycetoma, a large variety of grains can be formed. These grains can be of different color, size, and consistency, depending on the causative microorganism. In general, fungal causative agents form black or white grains, while bacterial causative agents have a more diverse color pallet of grains ranging from red and yellow to white (Table 1). Although the color of the grain can be indicative of the causative agent, it cannot be relied upon for the final identification. In the past, yellow grains were always
Correspondence: Wendy WJ van de Sande Department of Medical Microbiology and Infectious Diseases, Erasmus MC, Wytemaweg 80, 30I5CE Rotterdam, the Netherlands

Email w.vandesande@erasmusmc.nl submit your manuscript | www.dovepress.com

Dovepress

http://dx.doi.org/10.2147/RRTM.S53115 

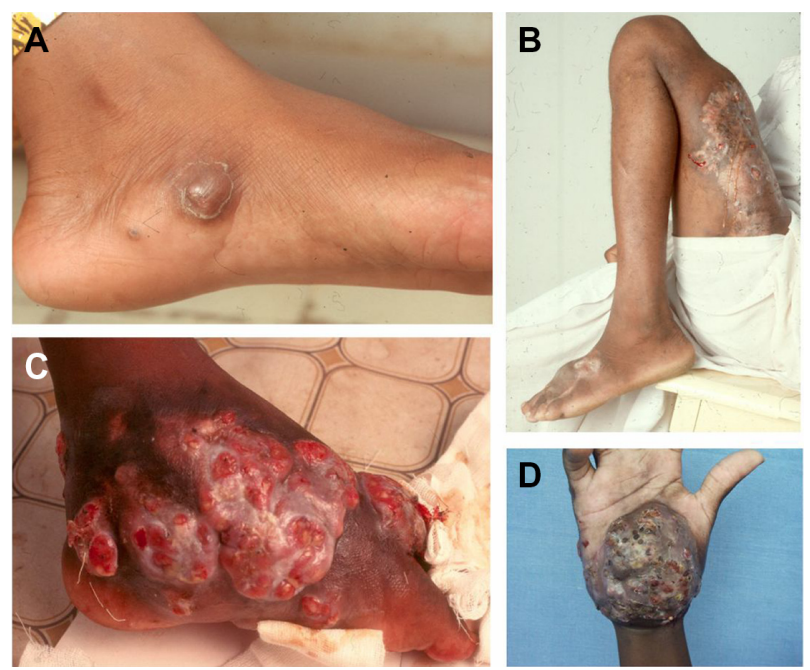

Figure I The clinical presentation of mycetoma.

Notes: In this figure four different cases of mycetoma are seen: (A) an early case of mycetoma of the foot, (B) a case of mycetoma in both the foot and the upper leg, (C) an advanced case of mycetoma of the foot, and (D) an advanced case of mycetoma of the hand.

considered to be of bacterial origin and therefore patients were treated with antibacterial agents when yellow grains were retrieved. ${ }^{6}$ Recently it was demonstrated that the fungus Pleurostomophora ochracea also produces yellow grains, which demonstrates the necessity of identifying the causative agent to the species level. ${ }^{6}$ Although the grain is one of the hallmarks of a mycetoma infection, the chemical composition of grains is still not fully understood. ${ }^{7}$ The grains of the most common causative agent Madurella mycetomatis have been demonstrated to contain lipids, proteins, dihydroxynaphtalene-melanin, $\mathrm{Cu}, \mathrm{Zn}$, and $\mathrm{Ca}^{6-8}$ Surrounding the grain, an extensive granuloma formation is present, characterized by a large zone of neutrophils surrounding the grain.

Although there are currently more than 56 different microorganisms recognized to cause mycetoma, the most prevalent causative agent of eumycetoma worldwide, and in Africa in particular, is the fungus M. mycetomatis. ${ }^{910}$ For example, in Sudan M. mycetomatis causes more than 70\% of all mycetoma infections. ${ }^{9,10}$

\section{Geographical distribution}

Mycetoma has a worldwide but uneven distribution. The disease is endemic in tropical and subtropical regions but the African continent has the highest prevalence. Mycetoma prevails in the mycetoma belt that stretches between the latitudes of $15^{\circ}$ south and $30^{\circ}$ north of the equator. ${ }^{1-3,11}$ The belt includes Sudan, Somalia, Senegal, India, Yemen, Mexico, Venezuela, Columbia, Argentina, and other countries. In Africa, Sudan seems to be the homeland of the disease. ${ }^{1,12-22}$ However, mycetoma has been reported in many temperate
Table I Etiologic agents causing mycetoma

\begin{tabular}{|c|c|c|}
\hline Species & Grain color & Prevalence $^{a}$ \\
\hline \multicolumn{3}{|l|}{ Actinomycetoma } \\
\hline Actinomadura madurae & $\mathrm{W} / \mathrm{Y} / \mathrm{P}$ & C \\
\hline Streptomyces somaliensis & $\mathrm{Y} / \mathrm{Br}$ & C \\
\hline Actinomadura pelletieri & Rd & C \\
\hline Nocardia brasiliensis & W & C \\
\hline Nocardia asteroides & W & C \\
\hline $\begin{array}{l}\text { Nocardia otitidiscaviarum (synonym: } \\
\text { Nocardia caviae) }\end{array}$ & $W / Y$ & O \\
\hline Actinomyces israelii & $W / Y$ & $\mathrm{R}$ \\
\hline Nocardia spp & $W / Y$ & \\
\hline Unidentified actinomycetes & & \\
\hline \multicolumn{3}{|l|}{ Eumycetoma } \\
\hline Madurella mycetomatis & B & $\mathrm{C}$ \\
\hline $\begin{array}{l}\text { Scedosporium boydii (synonyms: } \\
\text { Scedosporium apiospermum, } \\
\text { Pseudallescheria boydii) }\end{array}$ & W & O \\
\hline $\begin{array}{l}\text { Falciformispora senegalensis } \\
\text { (synonym: Leptosphaeria senegalensis) }\end{array}$ & B & O \\
\hline $\begin{array}{l}\text { Trematosphaeria grisea (synonym: } \\
\text { Madurella grisea) }\end{array}$ & B & 0 \\
\hline $\begin{array}{l}\text { Acremonium falciforme (synonym: } \\
\text { Cephalosporium falciforme) }\end{array}$ & w & $\mathrm{R}$ \\
\hline Aspergillus fumigatus & & $\mathrm{R}$ \\
\hline Exophiala jeanselmei & B & $\mathrm{R}$ \\
\hline Geotrichum candidum & & $\mathrm{R}$ \\
\hline Neotestudina rosatii & W & $\mathrm{R}$ \\
\hline Medicopsis romeroi & B & $\mathrm{R}$ \\
\hline $\begin{array}{l}\text { M. romeroi or Biatriospora mackinnonii } \\
\text { (synonym: Pyrenochaeta spp) }\end{array}$ & B & $\mathrm{R}$ \\
\hline Aspergillus flavus & G & $\mathrm{R}$ \\
\hline Microsporum audouinii & W & $\mathrm{R}$ \\
\hline Cochliobolus lunatus (synonym: & B & $R$ \\
\hline Curvularia lunata) & & \\
\hline Rhinocladiella atrovirens & & $\mathrm{R}$ \\
\hline Aspergillus nidulans & W & $\mathrm{R}$ \\
\hline Neoscytalidium dimidiatum & & $\mathrm{R}$ \\
\hline Fusarium spp & W & \\
\hline Cladosporium spp & & \\
\hline Exophiala spp & B & \\
\hline Unidentified fungi & & \\
\hline
\end{tabular}

Notes: aprevalence: C, species isolated $>5 \%$; O, species isolated $1 \%-5 \%$; R, rare species isolated $<1 \%$. Reproduced from: van de Sande WW. Global burden of human mycetoma: a systematic review and meta-analysis. PLoS Negl Trop Dis. 2013;7(I I):e2550.10

Abbreviations: B, black; $\mathrm{Br}$, brown; C, common; G, green; O, occasional; P, pink; $\mathrm{R}$, rare; $\mathrm{W}$, white; $\mathrm{Y}$, yellow; Rd, red.

regions as well. ${ }^{23-25}$ There are a few reports on mycetoma from the USA, France, Germany, the UK, Turkey, Egypt, Saudi Arabia, Iran, Thailand, and Japan. ${ }^{23-32}$

To date, its true incidence, prevalence, and route of infection are not well understood, due to the fact that mycetoma is not a reportable disease..$^{33}$ Globally, various singlecenter studies have been performed to estimate the disease prevalence in certain areas. ${ }^{10}$ As far as we are aware, only two large epidemiological studies have been performed to estimate the disease prevalence throughout whole countries. 
These studies were performed in Sudan and in Mexico. ${ }^{19,34}$ The study performed by Abbott in Sudan during the period 1952-1955 was the first large study; ${ }^{34}$ the study performed by López Martínez et al in Mexico between 1956 and 1985 was the second. ${ }^{19}$ In the first study, 1,231 mycetoma patients were admitted to hospitals throughout the country over a period of 2.5 years and the estimated prevalence was calculated as 4.6 per 100,000 inhabitants. ${ }^{34}$ López Martínez et al reported on 2,105 mycetoma cases from 14 dermatological centers throughout Mexico over a period of 30 years and estimated a prevalence of 0.6 per 100,000 inhabitants. ${ }^{19}$ Since in both these studies only hospital records were searched, underestimated prevalences were retrieved. Even though the prevalences were underestimated, they are still comparable to those of other neglected tropical infections such as Buruli ulcer, African trypanosomiasis, dracunculiasis, and leprosy. ${ }^{10,33}$

Next to these nationwide prevalence studies, several single-center studies have been reported as well. These studies were used by van de Sande in 2014 to perform a large meta-analysis. ${ }^{10}$ In that meta-analysis, 8,763 cases from various countries were reviewed. ${ }^{10}$ The countries included were India, Mexico, Niger, and Sudan. The estimation of the prevalence per country was calculated. Prevalence ranked between 3.49 cases per 100,000 inhabitants and $<0.01$ cases per 100,000 inhabitants. In Sudan the prevalence was 1.81 cases per 100,000 inhabitants, but in local villages this appeared to be much higher. ${ }^{10}$ In this metaanalysis the prevalence was underestimated, since the number of cases from only a small region was divided through the population of the whole country. ${ }^{10}$ This also explained the differences of the calculated prevalences from $\mathrm{Abbott}^{34}$ and van de Sande ${ }^{10}$ for Sudan and the reported prevalences of surveys performed in mycetoma-endemic villages in Sudan. In these mycetoma-endemic villages a prevalence ranging from 0.0 to 8.5 per 1,000 inhabitants was suggested. ${ }^{10,33,35,36}$ A higher reported prevalence is expected in the near future, as mycetoma is drawing more attention from researchers and local authorities. In Sudan, a national Mycetoma Research Center (MRC; located in the capital Khartoum), was established in 1991. In this center more than 6,700 patients have been seen and treated, but this has not been reported in the literature Fahal et al. The center serves as a centralized focal point for mycetoma diagnosis, treatment, and health education. Most of the cases are derived from states, cities, and villages outside Khartoum. Gezira state, for instance, comprises more than $80 \%$ of the total number of cases reported in the MRC in Khartoum. ${ }^{37}$
The distance from Gezira to Khartoum is about $190 \mathrm{~km}$, making a trip to the MRC difficult and expensive since the majority of the patients are of low socioeconomic status. This results in late presentation due to the painless, slowly progressive nature of the disease, and the lack of health education. Thus, establishing satellite centers will improve the management for people living to far from the main mycetoma research centre. By opening centers in te vicinity of high burden regions, more people will seek help and will be treated.

Mycetoma has only recently been included in the World Health Organization Department of Neglected Tropical Diseases list as another condition, and hopefully this recognition will in the future lead to better prevalence numbers - for instance, by making mycetoma a reportable disease like Buruli ulcer.

\section{Affected groups and management}

The prevalence studies mentioned in the previous section demonstrated that mycetoma is mainly found in young adults. ${ }^{10,12-26,28-34}$ In most countries, males are more often infected than females. ${ }^{10,12-26,28-34}$ Although most cases are found in this age group, no age is exempted. ${ }^{19}$ Mycetoma is also reported in children and elderly. ${ }^{38}$ Most of the patients are students, farmers, and workers of low socioeconomic status and eventually they lose their chance of education and jobs due to the disability caused by what is a curable and preventable disease. ${ }^{10,36,39}$ Due to ignorance and lack of health education, many patients present late with advanced disease and amputation may be the only available treatment modality of choice.

\section{Treatment of mycetoma}

The treatment of mycetoma depends mainly on the etiological agent, site of infection, and extent of the disease. Until recently, the only available treatment for mycetoma was amputation or multiple mutilating disfiguring surgical excisions, as no therapeutic consensus has been reached. Actinomycetoma is usually treated with medication only. ${ }^{40}$ For eumycetoma, a combination of medical treatment in the form of antifungals and various surgical excisions is the gold standard. ${ }^{40-42}$ As already mentioned, due to ignorance and lack of health education, many patients present late with advanced disease and amputation may be the only available treatment modality of choice.

Mycetoma has many serious medical and socioeconomic impacts on patients, communities, and health authorities. ${ }^{43}$ The postoperative recurrence rate varies from $25 \%$ to $50 \%$. ${ }^{1,41,44-46}$ The available treatment, although not very 
effective, has many side effects. The medicines are expensive and the cost may reach more than US\$3,000 per year, per patient in the case of eumycetoma. Most of the patients cannot afford these costs of treatment. Furthermore, the drugs are not always available in endemic regions. The treatment is of a variable duration and may continue for 2-3 years with a mean duration of 18 months. Therefore, herbal and home remedies are widely practiced by the population living in endemic areas, which further complicates the matter. ${ }^{47}$

Currently there are no preventive measures or control programs for mycetoma worldwide.

\section{Treatment of eumycetoma}

Reports on the medical treatment of eumycetoma are insufficient and inadequate. Over the years, the treatment of eumycetoma was based on personal clinical experience and on the results of sporadic case reports, rather than controlled clinical trials. In general, massive surgical excisions or amputation of the affected part is/are the treatment of choice for eumycetoma. ${ }^{41,44-46}$ Various antifungal agents have been tried with little success. Eumycetoma causative agents are in vitro highly susceptible toward azole antifungal agents, and their eradication should be readily achieved by the administration of antifungal drugs. ${ }^{48-51}$ Antifungal therapy consists mainly of ketoconazole or itraconazole combined with surgical excision. ${ }^{46,52,53}$ Data obtained from the MRC showed that, of 1,242 eumycetoma patients studied, only 321 (25.9\%) were cured, 35 (2.8\%) had amputations, and 671 dropped out from the outpatient follow-up for various reasons. ${ }^{46}$ Among these reasons was dissatisfaction with therapy outcome. ${ }^{46}$ Other reasons included side effects, such as hepatic toxicity; gynecomastia; and skin discoloration. Next to that, in a recent study it appeared that the outcome of antifungal therapy could be improved when the patient was also treated with antibiotics to clear the side-infections commonly occurring in open mycetoma wounds. ${ }^{54,55}$ As a result, most patients stopped therapy, were lost to follow-up in outpatient clinics, and presented late with a massive relapse that often required amputation. ${ }^{46}$

\section{Treatment of actinomycetoma}

Generally, actinomycetoma is amenable to medical treatment with antibiotics and other chemotherapeutic agents. ${ }^{40,56}$ Combined drug therapy is always preferred to a single drug in order to avoid drug resistance and for disease eradication. ${ }^{56}$ Back in the 1970s, Mahgoub obtained a relatively successful cure rate by administrating sulfamethoxazole plus streptomycin to 144 patients with actinomycetoma. ${ }^{57}$ In that study, $63.2 \%$ of the patients were cured, $21.5 \%$ greatly improved, and $11.1 \%$ showed some improvement. ${ }^{57}$ Currently, trimethoprim-sulfamethoxazole is considered to be the most effective drug treatment for uncomplicated mycetoma cases, although the duration of the therapy is still very long. It has to be given for several months to reach complete cure. ${ }^{46,56}$ In advanced cases, a combination of medical treatment with antibiotics and excision of the lesion by surgery accelerates healing, and reduces the chance of relapse; however a good number of patients respond to treatment with antibiotics alone. ${ }^{40}$ Recurrence is more common after an incomplete or irregular course of medical treatment. ${ }^{40,56}$ With patient noncompliance, there is a good chance that the organism will develop drug resistance. ${ }^{46}$

\section{Conclusion}

Mycetoma has a global distribution but is most commonly found in the so-called mycetoma belt, between $15^{\circ}$ south and $30^{\circ}$ north of the equator. Within the highly endemic regions most cases are found in males between 15 and 40 years of age. Since mycetoma is still not a reportable disease, the true prevalence of this disease is still unknown. Mycetoma can be caused by a large variety of microorganisms, both fungi and bacteria, and treatment depends on the causative agent and the personal experience of the physician. Mycetoma patients in general tend to present late to clinics. This could be due to the painless nature of the disease but also to the long distance some patients are from specialized clinics. Epidemiological data are needed to determine in which regions the largest burden of mycetoma can be found. Within these regions specialized medical care for mycetoma needs to be made available. In general actinomycetoma responds very well to antibiotic treatment only, while eumycetoma needs a combination of antifungal treatment and surgery and even then recurrent infections are common.

There is a great need to determine the current burden of this disease in order to establish clinics in the vicinity of the patients. In addition, guidelines should be prepared which state what the best treatment for each type of mycetoma is. Research should be focused on the development of novel treatments, since the current treatments, especially for eumycetoma, are failing.

\section{Disclosure}

The authors declare no conflicts of interest in this work.

\section{References}

1. Fahal AH. Mycetoma. Khartoum Medical Journal. 2011;4(1): 514-523.

2. Fahal AH. Mycetoma: a thorn in the flesh. Trans R Soc Trop Med Hyg. 2004;98(1):3-11. 
3. Fahal AH, Hassan MA. Mycetoma. Br J Surg. 1992;79(11): 1138-1141.

4. de Hoog GS, Ahmed SA, Najafzadeh MJ, et al. Phylogenetic findings suggest possible new habitat and routes of infection of human eumyctoma. PLoS Negl Trop Dis. 2013;7(5):e2229.

5. Ahmed A, Adelmann D, Fahal A, Verbrugh H, van Belkum A, de Hoog S. Environmental occurrence of Madurella mycetomatis, the major agent of human eumycetoma in Sudan. $J$ Clin Microbiol. 2002;40(3):1031-1036.

6. Mhmoud NA, Ahmed SA, Fahal AH, de Hoog GS, Gerrits van den Ende AH, van de Sande WW. Pleurostomophora ochracea, a novel agent of human eumycetoma with yellow grains. J Clin Microbiol. 2012;50(9):2987-2994.

7. Ibrahim AI, El Hassan AM, Fahal A, van de Sande WW. A histopathological exploration of the Madurella mycetomatis grain. PLoS One. 2013;8(3):e57774.

8. van de Sande WW, de Kat J, Coppens J, et al. Melanin biosynthesis in Madurella mycetomatis and its effect on susceptibility to itraconazole and ketoconazole. Microbes Infect. 2007;9(9):1114-1123.

9. van de Sande WW, Fahal AH, Goodfellow M, Mahgoub el S, Welsh O, Zijlstra EE. Merits and pitfalls of currently used diagnostic tools in mycetoma. PLoS Negl Trop Dis. 2014;8(7):e2918.

10. van de Sande WW. Global burden of human mycetoma: a systematic review and meta-analysis. PLoS Negl Trop Dis. 2013;7(11):e2550.

11. Ahmed AO, van Leeuwen W, Fahal A, van de Sande W, Verbrugh H, van Belkum A. Mycetoma caused by Madurella mycetomatis: a neglected infectious burden. Lancet Infect. Dis. 2004;4(9):566-574.

12. Cameron HM, Gatei D, Bremner AD. The deep mycoses in Kenya: A histopathological study. 1. Mycetoma. East Afr Med J. 1973;50(8): 382-395.

13. Develoux M, Audoin J, Treguer J, Vetter JM, Warter A, Cenac A. Mycetoma in the Republic of Niger: clinical features and epidemiology. Am J Trop Med Hyg. 1988;38(2):386-390.

14. Develoux M, Dieng MT, Kane A, Ndiaye B. [Management of mycetoma in West-Africa.] Bull Soc Pathol Exot. 2003;96(5):376-382. French.

15. Develoux M, Ndiaye B, Dieng MT. [Mycetomas in Africa.] Sante. 1995;5(4):211-217. French.

16. Agarwal SC, Mathur DR. Mycetoma in northern Nigeria. Trop Geogr Med. 1985;37(2):133-135.

17. Buot G, Lavalle P, Mariat F, Suchil P. [Epidemiologic study of mycetomas in Mexico. Apropos of 502 cases.] Bull Soc Pathol Exot Filiales. 1987;80(3):329-339. French.

18. Lavalle P. [New data on the etiology of mycetoma in Mexico and on its pathogenesis.] Gac Med Mex. 1966;96(6):545-574. Spanish.

19. López Martínez R, Méndez Tovar LJ, Lavalle P, Welsh O, Saúl A, Macotela Ruíz E. [Epidemiology of mycetoma in Mexico: study of 2105 cases.] Gac Med Mex. Jul-1992;128(4):477-481. Spanish.

20. Negroni R. Contribucion al estudio de los micetomas en la Republica Argentina [Mycetomas in the Argentine Republic]. Med Cutan Ibero Lat Am. 1974;2(5):353-362. Spanish.

21. Singh H. Mycetoma in India. Indian J Surg. 1978;41:577-597.

22. Khatri ML, Al-Halali HM, Fouad Khalid M, Saif SA, Vyas MC. Mycetoma in Yemen: clinicoepidemiologic and histopathologic study Int J Dermatol. 2002;41(9):586-593.

23. Green WO Jr, Adams TE. Mycetoma in the United States; a review and report of seven additional cases. Am J Clin Pathol. 1964;42:75-91.

24. Hay RJ, Mackenzie DW. Mycetoma (madura foot) in the United Kingdom - a survey of forty-four cases. Clin Exp Dermatol. 1983;8(5): 553-562.

25. Mattioni S, Develoux M, Brun S, et al. Management of mycetomas in France. Med Mal Infect. 2013;43(7):286-294.

26. El-Mofty AM, Iskander IO, Nada M, Zaki SM. Madura foot" in Egypt. Br J Dermatol. 1965;77:365-372.

27. Schiefer B, Mehnert B. [Maduromycosis in horses in Germany.] Berl Munch Tierarztl Wochenschr. 1965;78(12):230-234. German.

28. Erbakan N, Or AN, Unal M, Palali Z. A review of mycetomas in Turkey. Mycopathol Mycol Appl. 1973;51(1):105-113.
29. Bendl BJ, Mackey D, Al-Saati F, Sheth KV, Ofole SN, Bailey TM. Mycetoma in Saudi Arabia. J Trop Med Hyg. 1987;90(2):51-59.

30. Hashemi J, Nasrollahi A, Guerami M, Daei R, Pakshir K, Zibafar A. Mycetoma in Iran: study of 62 cases. Asian Journal of Epidemiology. 2008;1(2):77-81.

31. Kotrajaras R. Mycetoma, a review of seventeen cases seen at the Institute of Dermatology, Bangkok, Thailand. J Dermatol. 1981;8(2): 133-137.

32. Fukushiro R, Mariat F. Note sur un mycetome a Nocardia caviae observe au Japon [Note on a mycetoma due to Nocardia caviae seen in Japan]. Bull Soc Pathol Exot Filiales. 1965;58(2):185-188. French.

33. van de Sande WW, Maghoub el S, Fahal AH, Goodfellow M, Welsh O, Zijlstra E. The mycetoma knowledge gap: identification of research priorities. PLoS Negl Trop Dis. 2014;8(3):e2667.

34. Abbott P. Mycetoma in the Sudan. Trans R Soc Trop Med Hyg. 1956; 50(1):11-24; discussion, 24-30.

35. Federal Ministry of Health National Mycetoma Control Programme. Report on the Epidemiological Study on Mycetoma at El Andalous Village, The White Nile State. Federal Ministry of Health National Mycetoma Control Programme; nd. Available from: http://www.mycetoma. edu.sd/news\&events/pdf/AL\%20Andalous\%20final\%20report.pdf. Accessed February 19, 2014. Khartoum.

36. Fahal A, Mahgoub el S, El Hassan AM, et al. A new model for management of mycetoma in the Sudan. PLoS Negl Trop Dis. 2014;8(10):e3271.

37. Fahal A, Mahgoub el S, El Hassan AM, Abdel-Rahman ME. Mycetoma in the Sudan: an update from the Mycetoma Research Centre, University of Khartoum, Sudan. PLoS Negl Trop Dis. March 27 2015;9(3):e0003679. doi:10.1371/journal.pntd.0003679.PMID: 25816316

38. Fahal AH, Sabaa AH. Mycetoma in children in Sudan. Trans $R$ Soc Trop Med Hyg. 2010;104(2):117-121.

39. Fahal AH. Mycetoma, Clinicopathological Monograph. Khartoum: Khartoum University Press; 2006.

40. Welsh O, Al-Abdely HM, Salinas-Carmona MC, Fahal AH. Mycetoma medical therapy. PLoS Negl Trop Dis. 2014;8(10):e3218.

41. Fahal AH. Management of mycetoma. Expert Rev Dermatol. 2010;5(1): $87-93$.

42. Ahmed AA, van de Sande WW, Fahal A, Bakker-Woudenberg I, Verbrugh $\mathrm{H}$, van Belkum A. Management of mycetoma: major challenge in tropical mycoses with limited international recognition. Curr Opin Infect Dis. 2007;20(7):146-151.

43. Mahgoub S. Medical treatment of mycetoma. Sudan Med J. 1994; 32(Suppl):88-97.

44. Fahal A, Hassan M, Sanhouri M. Surgical treatment of mycetoma. Sudan Med J. 1994;32(Suppl):98-104.

45. Fahal AH, Shaheen S, Jones DH. The orthopaedic aspects of mycetoma. Bone Joint J. 2014;96-B(3):420-425.

46. Zein HA, Fahal AH, Mahgoub el S, El Hassan TA, Abdel-Rahman ME Predictors of cure, amputation and follow-up dropout among patients with mycetoma seen at the Mycetoma Research Centre, University of Khartoum, Sudan. Trans R Soc Trop Med Hyg. 2012;106(11): 639-644.

47. Ezaldeen EA, Fahal AH, Osman A. Mycetoma herbal treatment: the Mycetoma Research Centre, Sudan experience. PLoS Negl Trop Dis. 2013;7(8):e2400.

48. Ahmed AO, van de Sande WW, van Vianen W, et al. In vitro susceptibilities of Madurella mycetomatis to itraconazole and amphotericin B assessed by a modified NCCLS method and a viability-based 2,3bis(2-methoxy-4-nitro-5-sulfophenyl)-5-[(phenylamino)carbonyl]-2Htetrazolium hydroxide (XTT) assay. Antimicrob Agents Chemother. 2004;48(7):2742-2746.

49. Kloezen W, Meis JF, Curfs-Breuker I, Fahal AH, van de Sande WW. In vitro antifungal activity of isavuconazole against Madurella mycetomatis. Antimicrob Agents Chemother. 2012;56(11): 6054-6056. 
50. van de Sande WW, Luijendijk A, Ahmed AO, Bakker-Woudenberg IA, van Belkum A. Testing of the in vitro susceptibilities of Madurella mycetomatis to six antifungal agents by using the Sensititre system in comparison with a viability-based 2,3-bis(2-methoxy-4-nitro-5sulfophenyl)-5-[(phenylamino)carbonyl]-2H-tetrazolium hydroxide (XTT) assay and a modified NCCLS method. Antimicrob Agents Chemother. 2005;49(4):1364-1368.

51. van Belkum A, Fahal AH, van de Sande WW. In vitro susceptibility of Madurella mycetomatis to posaconazole and terbinafine. Antimicrob Agents Chemother. 2011;55(4):1771-1773.

52. Mahgoub ES, Gumaa SA. Ketoconazole in the treatment of eumycetoma due to Madurella mycetomii. Trans R Soc Trop Med Hyg. 1984;78(3):376-379.

53. Fahal AH, Rahman IA, El-Hassan AM, Rahman ME, Zijlstra EE. The safety and efficacy of itraconazole for the treatment of patients with eumycetoma due to Madurella mycetomatis. Trans $R$ Soc Trop Med Hyg. 2011;105(3):127-132.
54. Ahmed AO, Abugroun ES. Unexpected high prevalence of secondary bacterial infection in patients with mycetoma. J Clin Microbiol. 1998;36(3):850-851.

55. Mhmoud NA, Fahal AH, Mahgoub el S, van de Sande WW. The combination of amoxicillin-clavulanic acid and ketoconazole in the treatment of Madurella mycetomatis eumycetoma and Staphylococcus aureus co-infection. PLoS Negl Trop Dis. 2014;8(6):e2959.

56. Welsh O, Vera-Cabrera L, Welsh E, Salinas MC. Actinomycetoma and advances in its treatment. Clin Dermatol. 2012;30(4):372-381.

57. Mahgoub ES. Treatment of actinomycetoma with sulphamethoxazole plus trimethoprim. Am J Trop Med Hyg. 1972;21(3):332-335.

\section{Publish your work in this journal}

Research and Reports in Tropical Medicine is an international, peerreviewed, open access journal publishing original research, case reports, editorials, reviews and commentaries on all areas of tropical medicine, including: Diseases and medicine in tropical regions; Entomology; Epidemiology; Health economics issues; Infectious disease; Laboratory science and new technology in tropical medicine; Parasitology; Public health medicine/health care policy in tropical regions; and Microbiology. The manuscript management system is completely online and includes a very quick and fair peer-review system. Visit http://www.dovepress. com/testimonials.php to read real quotes from published authors. 